\title{
Probable Protein E4, Human Papillomavirus Type 11
}

National Cancer Institute

\section{Source}

National Cancer Institute. Probable Protein E4, Human Papillomavirus Type 11. NCI

Thesaurus. Code C17519.

Probable protein E4 (180 aa, $\sim 12 \mathrm{kDa}$ ) is encoded by the human papillomavirus type 11 E4 gene. This protein is an early phase product and its function is unknown. 